Ил ь н и ц и й А. П., 1971. Загрязнение водоемов канцерогенными веществами и меры его профилактики. В сб.: Канцерогенные вещества во внешней среде. М.: 29-41. Ильни иц и й А. П., Коган Ю. Л., Скворцов а Н. Н., Е ршова К. П., Гвиль д и с В. Ю., 1972. Методические указания по отбору проб из объектов внешней среды и их подготовке к анализу на канцерогенные полициклические ароматические углеводороды. М.

К о г а Ю. Л., 1972. О загрязнении почвы и растительности канцерогенными углеводородами (изучение содержания бенз (а)пирена). Автореф. канд. дисс. М.

М и л ь ко в Ф. Н., 1973. Человек и ландшафты. М.

Н ы м м и к С. Я., 1970. Сущность, задачи и метод дробного экономического районирова ния (на примере Әстонской ССР). Автореф. докт. дисс. Тарту.

Ш а б а д Л. М., 1973. О циркуляции канцерогенов в окружающей среде. М.

Институт экспериментальной и клинической медицины Министерства здравоохранения Эстонской ССР

Поступила в редакцию $30 / 11974$

Ннститут экспериментальной и клинической онкологии Академии медицинских наук СССР

EESTI NSV TEADUSTE AKADEEMIA TOIMETISED, 24. KOIDE

KEEMIA * GEOLOOGIA. 1975, Nr. 3

ИЗВЕСТИЯ АКАДЕМИИ НАУК ЭСТОНСКОИ ССР. ТОМ 24 ХИМИЯ * ГЕОЛОГИЯ. 1975 , № 3

удК 547.56:547.68:628.356

Майла ХАННУС, Ууве КИРСО, М. ГУБЕРГРИЦ

\title{
КИНЕТИКА СОВМЕСТНОГО БИОХИМИЧЕСКОГО ОКИСЛЕНИЯ 3,4-БЕНЗПИРЕНА И ФЕНОЛОВ НА АДАПТИРОВАННЫХ АКТИВНЫХ ИЛАХ
}

Maila HANNUS, Uuve KIRSO, M. GUBERGRITS, 3,4-BENSOPOREENI JA FENOOLIDE KOOS OKSODEERIMISE KINEETIKA AKTIIVMUDADEL

Maila HANNUS, Uuve KIRSO, M. GUBERGRITS. KINETICS OF THE BIOCHEMICAL COOXIDATION OF 3,4-BENZOPYRENE AND PHENOLS IN ACTIVATED SLUDGES

Попадая в биосферу, канцерогенные полициклические углеводороды, в том числе и 3,4-бензпирен (БП), подвергаются биоокислению под действием микроорганизмов, предварительно адаптированных к нему $\left[{ }^{1-3}\right]$. В составе загрязнений ореды БП сопутствуют разные фенолы. Эффективным способом их обезвреживания считается биоокисление на адаптированных к ним активных илах. До настоящего времени попытки использования активного ила, адаптированного к фенолу, для разложения БП не дали положительного результата $[4,5]$. Целью настоящей работы явилось установление принципиальной возможности применения для биоокисления в водной среде БП активных илов, адаптированных к двум видам фенольных субстратов: собственно фенолу и смеси алкилпроизводных резорцина из сточных вод сланцехимического производства, а также кинетическая оценка процесса совместного биоокисления БП и указанных фенолов.

Эксперимент проведен по методике, описанной нами ранее [ $\left.{ }^{6-8}\right]$, исходная концентрация БП составляла $4 \cdot 10^{-7}$ моль $/ \Omega$, фенолов $-5 \cdot 10^{-3}$ моль $/ \Omega$. 
Анализ БП произведен после экстракции его эфиром по квазилинейчатым спектрам флуоресценции при температуре жидкого азота [].

Кинетика деградации фенолов раздельно и совместно с БП изображена на рис. 1. Константы скорости разложения фенола, рассчитанные по формально-кинетическому уравнению псевдонулевого порядка, составляют 7,3 и $5,5 \cdot 10^{-5}$ моль/ $/ \cdot$ мин; для смеси сланцевых фенолов они равны соответственно 5,4 и $4,3 \cdot 10^{-5}$ моль $/ \Omega \cdot$ мин. Таким образом, присутствие БП замедляет процесс биоокисления фенолов в среднем на $30 \%$.
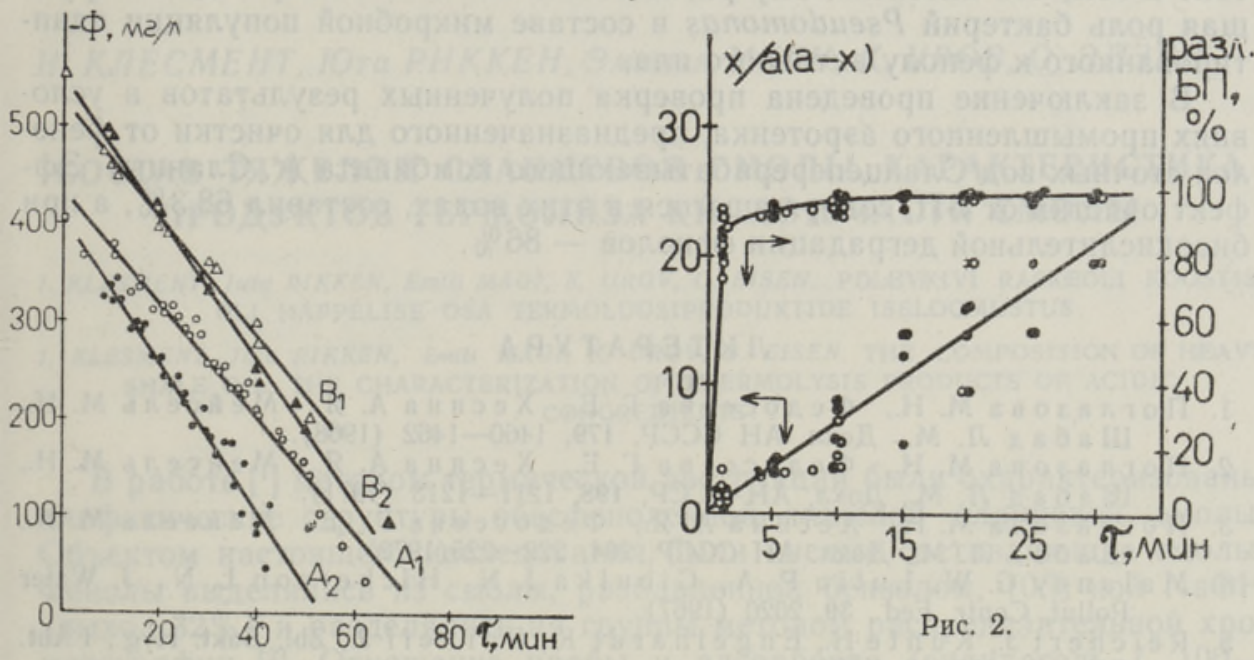

Рис. 2.

Рис. 1.

Окислительное разложение БП на активных илах, адаптированных к указанным фенольным субстратам, происходит с большой скоростью в начальной стадии процесса (в первые же минуты проведения опыта), а в последующем замедляется (см. рис. 2). Обработка результатов показывает, что процесс отвечает макрокинетическому уравнению второго порядка. Коэффициент корреляции при определении величины константы скорости суммарной реакции составляет 0,92. При этом скорость биоокисления БП не зависит от природы фенольного субстрата, к которому адаптирован активный ил. Для всех случаев константа скорости деградации БП равна $6,8 \cdot 10^{8} \Omega /$ моль $\cdot$ мин.

Количество БП, повергшегося разложению после смешения раствора с активным илом, составляет в среднем $70-80 \%$ от исходного, причем около $10 \%$ последнего остается в неразложенном состоянии в растворе и примерно та же доля приходится на БП, сорбированный биомассой (потери его в опыте не превышают $3 \%$ ). Микроорганизмы активного ила не теряют способности к разложению нового количества БП. Итак, установлено, что после разложения на данном активном иле в первом опыте $78,5 \%$ БП эта же биомасса способна разложить новую порцию БП на $72 \%$, причем суммарное количество разложенного БП достигает 8,5. $\cdot 10^{-5} 2$.

Нами проверена также возможность обратного перехода БП из активного ила в раствор. Фактический возврат его весьма незначителен (до $0,8 \%$ от исходного реагента).

Скорость биохимического окисления БП на устойчиво адаптированных к фенолам активных илах в условиях настоящего исследования оказывается весьма значительной. Она на несколько порядков величин пре- 
вышает кинетический показатель, определенный с известным приближением $\left[{ }^{10}\right]$ для эксперимента Поглазовой и др. $\left[{ }^{1-3,11}\right]$ при деградации БП в составе сточных вод на собственной микрофлоре и даже при добавке специально культивированных микроорганизмов. Это явление, очевидно, обусловлено двумя причинами. Первая из них заключается в том, что фенолы, которые служат питателыным веществом для адаптированного к ним активного ила, вероятно, оказывают ускоряющее биохимическое воздействие на процесс биодеградации БП. Вторая причина состоит в том, что интенсивному разложению БП способствует доминирующая роль бактерий Pseudomonas в составе микробной популяции адаптированного к фенолу активного ила.

В заключение проведена проверка полученных результатов в условиях промышленного аэротенка, предназначенного для очистки от фенолов сточных вод Сланцеперерабатывающего комбината (г. Сланцы). Эффект очистки от БП, содержащегося в этих водах, составил $68,3 \%$, а при биоокислительной деградации фенолов - $86 \%$.

\section{Л ИТ Е РА Т У Р А}

1. Поглазова М. Н., Федосеева Г. Е., Хесина А. Я., Мейсель М. Н., Ш а б а д Л. М., Докл. АН СССР, 179, 1460-1462 (1968).

2. Поглазова М. Н., Федосеева Г. Е., Хесина А. Я., Мейсель М. Н., Ш а б а д Л. М., Докл. АН СССР, 198, 1211-1213 (1971).

3. Поглазова М. Н., Хесина А. Я., $\Phi$ едосеева Г. Е., Мейсель М. Н. Ш а 6 а д Л. М., Докл. АН СССР, 204, 222-225(1972).

4. Malaney G. W., Lut in P. A., Cibulka J. N., Hickerson L. N., J. Water Pollut. Contr. Fed., 39, 2020 (1967).

5. Reichert J., Kunte H., Eng el hardt K., B orneff J., Zbl. Bakt. Hyg., 1 Abt. Orig. B., 155, 18 (1971).

6. Х а н н ус М., К и р со У., Изв. АН ЭССР. Хим. Геол., 23, 193 (1974).

7. Х анн ус М., Ки р со У., Л е эсмент Л., Изв. АН ЭССР. Хим. Геол., 22, $82-84$ (1973).

8. Кирсоу. Э., Берновская Н. А., Ханнус М. Г., Губергриц М. Я., В и й т м а а Э. Х., В сб. Матер. IV Всесоюзн, симп. по совр. проблемам самоочнщения и регулир. качества воды, Таллин, 1972, с. 62.

9. Фед досе в а Г. Е., Х е с ин а А. Я., Ж. прикл. спектроск. 9, 282-288 (1968).

10. Па альме Л., Губе ргриц М., Изв. АН ЭССР. Хим. Геол., 23, 283 (1974).

11. Поглазова М. Н., Федосеева Г. Е., Хесина А. Я., МейсельМ. Н., Ш а б а д Л. М., Докл. АН СССР, 169, 1174-1177 (1966).

$\begin{array}{cc}\text { Институт химии } & \text { Поступила в редакцию } \\ \text { Академии наук Эстонской ССР } & 28 / \text { III } 74 \\ \text { Таллинский политехнический институт } & \end{array}$

